\title{
The influence of Green Marketing on Decision Purchasing Organic Products with Interests of Buying as an Intervening Variable at Manado City, Indonesia
}

\author{
Allen A. Ch. Manongko ${ }^{1}$, Joseph Kambey ${ }^{2}$ \\ ${ }^{1}$ Faculty of Economics, Universitas Negeri Manado-Indonesia \\ ${ }^{2}$ Faculty of Economics, Universitas Negeri Manado-Indonesia
}

\begin{abstract}
This research attempts to test and analyze the influence of green marketing on the customers' decision tobuy organic product with the interest to buy as an intervening variable. This is an explanatory research withquantitative method and survey method. The modelling refer to the theories of marketing mix and plannedbehaviour. The research population are customers who buy organic products at the supermarket or modernmarket in Manado city, Indonesia. The samples are 120 respondents. The sampling was conducted bypurposive sampling technique and data analysis techinique. It also involves confirmatory factor analysis andpath analysis, with SPSS 18 application. The result shows following facts: green marketing does not havedirect and significant influence on customers' buying attitude; green marketing does not have direct andsignificant influence on customers' purchase decision; buying interest has direct and significant influenceon the customers' decision; green marketing does not have direct and significant influence on customers'decision with buying interest as the intervening variable.
\end{abstract}

Keywords: Green Marketing; Interest to Buy; Purchase Decision; Organic Product

\section{Introduction}

Climate change and global warming are no longer simply the issue disseminated by the scientists or attention-diverting issues from the world leaders. These phenomena have taken their forms and been evolving; thus, it can be said that the earth as a place to live in for humans and other creatures is under serious threat. Various natural phenomenon incline to experience anomaly recently such as prolonged extreme heat in some places, high intensity of precipitation leading to flood in some areas, tornadoes and land slides, as well as tsunamis. The emergence of new viruses such as bird flu, pig flu, mad cow and others shows the evidences that the earth has been severely contaminated. Due to these conditions, awareness and realization of having healthy environment have changed the point of view and life style of the businessmen in order to create and sustain the balance and controlled situation of the nature. The shift on business approach (production and marketing) has evidently shown these attitudes. The businessmen tend to conduct business activities based on natural preservation and health such as eco-friendly products and organic products.

Environmental marketing is the modification in marketing which also serve as potential and strategic opportunity because it gives multiflier effect for businessmen and society as users. Green marketing approach on products is assumed to strengthen control over the environmental issues, this approach also gives stimulus on the aspects of company's activities such as the formulation of strategy, planning, designing, production and distribution to customers. Nanere (2010) explain that green marketing refers to organization's effort in designing, promoting, setting the price, and distributing the products without posing harm to the environment. This statement is supported by Pujari and Wright (1995) and Kalafatis et al., (1999) who perceive green marketing as the potential for distributors, as the business opportunity to develop and implement the plan as the company's strategy.

Lozada (2000) explain that a company finds a solution to solve an environmental issue by choosing strategic marketing for product and service to compete with others. Green marketing is newly-emerging marketing 
strategy and widely known since the end of 20th century. This condition requires the marketers to be more meticulous and careful in taking decision related to environment.

Green marketing is perceived by the company as the chance to reach the company's goals. It is clearly seen from the interest of the businessmen in the environmental issues and health problems; thus, eco-friendly markets are on the rise (Laroche, et al., 2001). The great number of businessmen guarantee that their products can be accepted in market, so internasional standard organization (ISO) has established standards for those products (i.e organic product) with ISO-14000.

Organic product is one of eco-friendly products with the promise of health quarantee for the customers. Some researchers in Indonesia who discuss 'organic product marketing' expose some factors influencing interest and decision in purchasing organic products. Those factors are the combination of marketing and demographic characteristics (Haryadi, 2009; Ardianti, 2008; Junaedi, 2005). An empirical study on the decision of green buying states that this refers to an attitude considered beneficial for the environment. Some researchers apply some approaches such as demographic and psychographic aspects. Demographic aspect covers the characteristics of customers for example age, education, and income. Psychographic aspect includes the psychological and subjective characteristics of customers such as values, confidence and attitude (Sari, H, 2008; Solomon, 2007; Sistya, 2002; Fotopoulos and Krystallis, 2002).

Organic products which are free from chemical substances/pesticide are growing trends in countries around the globe. The shift of consumption pattern in which the customers start using organic products is an interesting phenomenon to discuss recently. The 'back to nature' life style is a wise decision to undergone healthy life. Green marketing in Indonesia is not quite popular despite its huge potential as it can be seen from the growing consumption pattern of eco-friendly products, in particular organic products (Kompas, 2007).

Some previous researchers explain that the changes in consumption pattern in which customers grow their interest, demand and attitude to buy organic food products are greatly influenced by some factors: health factor (Tarkiainen and Sundqvist, 2005; Chen, 2009; Kalafatis, et al.,1999), social status and life style (Tsakiridou et al., 2006).

The result from the observation, interview with the customers and supermarket's owners and the tracking on marketing and the availability of organic products in Manado show that the purchase volume of organic products has not increased yet. This happens due to the lack of varieties of organic products sold in either traditional or modern market, expensive price, the lack of marketing and understanding, and the disorganized distribution of the product from the suppliers.

To figure out, explain, and analyze marketing and customers' behavior to buy organic products in Manado, the researchers apply theory of planned behavior from Ajzen (1988) as the underlying theory. This theory aims at explaining and predicting the influence of interest dimensions such as attitude, subjective norms, and behavior control on the purchase behavior. Tarkiainen and Sundqvist (2005) modifies the theory of planned behavior by adding some variables; health awareness, price perception, and product availability. He places interest as the intervening variable to understand the recurrent customer's behavior to buy organic products in Finland. Magistris and Gracia (2008) conducted research on the influence of knowledge about organic products on the attitude and behavior of customers in buying organic foods in Italy. This research conjoined two variables as the antecedent variables which influence the customers' behavior on organic foods. Kalafatis, et al., (1999) digged out customers' behavior in buying green products by conducting cross research between customers in Greek and England by using theory of planned behavior without modifying the model. He made indirect connection between behaviour and behavior control to interest by using subjective norm. He found out that concerns on environment and customers' will have changed their purchase behavior by buying environmentally friendly products in a low correlation.

Due to the existing phenomenon, theoretical and empirical reviews, this research highlights the analysis and explication of green marketing influence with buying interest as the intervening variable in the decision of customers to buy organic products in Manado. This research recommends the benefit in theoretical and empirical aspects related to customers' behaviour. It intends to explain and comprehend factors influencing the customers' decision to buy organic products with green marketing concept and theory of planned behavior.

\section{Literature Review \\ Green Products}


Kasali (2005) defines green products as harmless products for human and environment. These products do not use much resource, produce excessive litters, nor involve violence to animals. Nugrahadi (2002) explains that green product is an environmentally friendly product. It was designed and processed to decrease negative effects which will pollute the environment during the production, distribution, and consumption. It is closely related to raw materials which can be recycled. Ottman (2006) posits that green product are typically durable, nontoxic, made from recycled materials or minimally packaged .

\section{Green Marketing Concept}

Nanere, (2010) explain that green marketing is the effort of an organization/company to design, promote, set price and distribute the environmentally friendly products. Polonsky, et al., (1998), define green marketing as All activities designed to generate and facilitate any exchange intended to satisfy human needs or wants, such that the satisfaction of these needs and wants occurs, with minimal detrimental impact on the natural environment. Lozada (2000) define green marketing as the application of marketing tool to facilitate changes by ensuring organizational satisfaction and individual purpose in the effort to maintain, protect and conserve physical environment. Charter (1992) defines green marketing as the hollistic and strategic responsibility. It refers to management process which identifies, anticipates, satisfies, and fullfils the needs of stakeholders to provide acknowledgement without posing dentrimental effect for humans or natural environment. Ottman (2006) mentions green marketing dimension by integrating environment into all marketing aspects such as the development of green product and green communication.

\section{Marketing Mix}

McCarthy classifies marketing tools into 4 big groups; product, price, promotion, and place (Kotler and Keller,(2007). Payne (2000) explains that the concept of marketing mix is a tool which is well-designed to be the structure for marketers. This concept consists of various marketing elements which must be considered to achieve success in implementing strategies of marketing segmentation, targeting, dan positioning in the targeting market. Therefore, marketing mix can be defined as the marketing function combined from various factors which can be controlled by an marketing organization. These factors can be mobilized to fulfill the needs of various types of customers. Stanton (1991) explains that marketing mix can be defined as the combination of four variables or activities which becomes the cores of marketing system in an organization consisting of product, price structure, promotion, and distribution system. Kotler (2000) states that marketing miz is a series of marketing tool which the company uses to achieve marketing goal in targeting market.

\section{Customer Behavior}

Customer behavior is a study which highlights a process undergone by someone or a group in selecting, choosing, buying, using and disposing a product, service, idea or experience to fulfil needs and wants (Solomon, 2002). According to Ma'ruf (2005), consumer behavior is a process in which a customer decides to buy, what to buy, where, when and how to buy. Thus, it can be stated that customer behavior is the sustainable process. Engel et. al, (1994) defines customer behavior as the activities in which the customers directly involve in the attempt to get, consume, and produce service and goods. It also includes the process of needs which proceeds and follows these activities. Based on those previous studies, customer behavior contains two important elements; decision making process and physical activities. Besides influenced by stimulus, customers' decision to buy product is also influenced by motivation. Customers have changing motivation on wants, perception, and preference. Sometimes, customers want to buy a product, but this interest soon eveporates and they donot want to buy the product. Producers must aware of these changing motivations in order to keep them. Thus, learning purchase motivation is ultimately important in marketing.

\section{Behavioral Interest}

Interest is one of psychological aspects which poses great influence on individual behavior. It also a motivation leading someone to perform certain activities or action (Schiffman and Kanuk, 2007). Behavioral interest is a function of theory of planned behavior which constitutes attitude, subjective norm, and behavioral control. Someone's intention to perform such behavior can be predicted from his/her attitude and way of thinking. Other people will figure out something when someone shows the attitude. Internal and 
external beliefs are perceived as the controlling aspects. Schiffman \& Kanuk (2007) explain that interest to buy is 'the emerging psychic activities due to affective and cognitive feelings on the desired goods and services'. Further, buying interest refers to a preference over an object which leads someone to try getting that object by spending money or sacrificing. In this research, interest serves as an intervening variable between green marketing variable and customers' decision on buying organic products'.

\section{Conceptual Framework}

Conceptual framework describes a comprehensive research paradigm which serves as theoretical framework and relationship and influence of research variables. The research aims at analyzing and explaining the influence of green marketing by placing buying interest as the intervening variable on the customers' decision to buy organic products in Manado. Based on conceptual framework, the correlation among variables is described in the following figure 1:

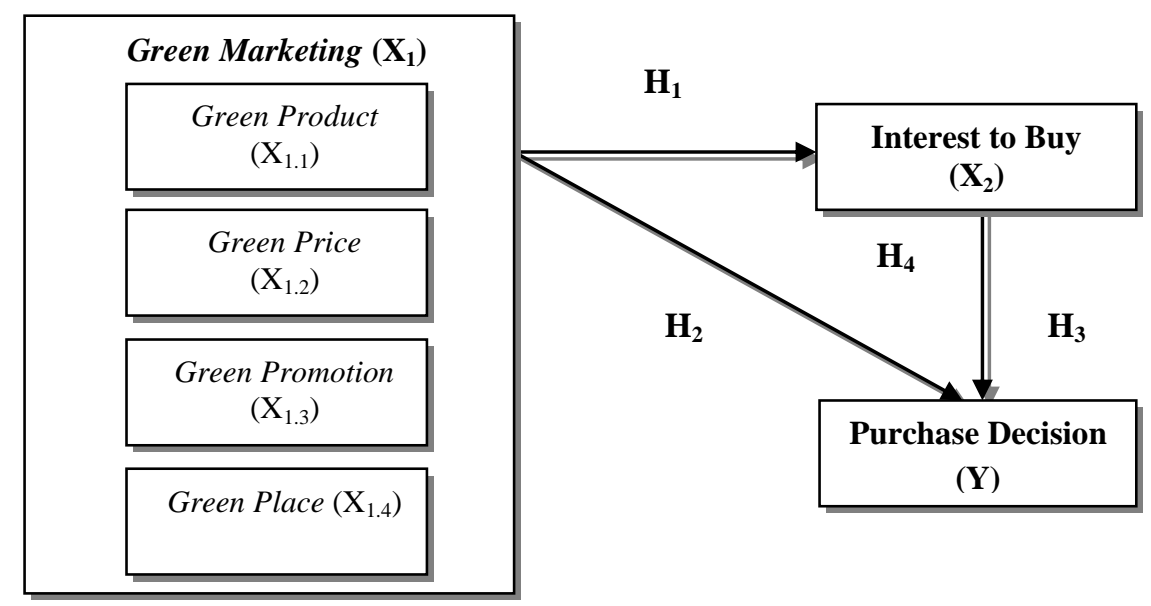

Figure 1. Conceptual framework

\section{Hypothesis}

H1 . Green Marketing has the influence on customers' interest to buy organic products.

H2 . Green Marketing has the influence on customers' decision to buy organic products

$\mathrm{H} 3$. Interest to buy influences the customers' decision to buy organic products

H4 . Green Marketing has the influence on the customers' decision through customers' interest to buy organic products.

\section{Method Research}

This research is an explanatory research with quantitative approach. This research was conducted in some modern markets (Fresh Supermarket, Golden Supermarket, dan Gelael Supermarket) in Manado and its adjacent areas. This research is one-shot study or cross sectional in which data are gathered in one period of time (Sekaran, 2006). Research population are all customers who have bought organic products at supermarkets in Manado. The samples of this population are 120 respondents which are selected based on the recommendation to use path analysis (Sarwono, 2007). Samples selection uses Non-probability sampling,method with purposive sampling technique (Ferdinand, 2006). The samples criterion is the customers who buy organic products. The independent variable is green marketing $\left(\mathrm{X}_{1}\right)$. The intervening variable is interest to buy $\left(\mathrm{X}_{2}\right)$. The dependent variable is purchase decision (Y). The data collecting used questionnaire, interview, and library research. The instrument to measure variable used in this research is likert scale which is able to measure attitude, opinion and perception of someone or a group on certain incidences or social symptoms (Sarwono, 2007). To measure validity, the researcher uses Pearson Product Moment which explains that: if $\mathrm{t}_{\text {hitung }}>\mathrm{t}_{\text {table }}$ or Sig $\mathrm{t}<0.05$, the data are valid; on the contrary, if $\mathrm{t}_{\text {hitung }}<\mathrm{t}$ table or Sig $t>0.05$, the data are not valid (Riduwan and Kuncoro, 2007). To measure reliability, the researcher uses alpha cronbach method which explains that: if $r_{11}>0.6$ it is considered reliable; on the contrary, if $\mathbf{r}_{11}<0.6$ it is not reliable (Riduwan and Kuncoro, 2007) .

This analysis aims at revealing data which have gathered from the research location. Data can be described by interpreting the result of data analysis in the form of frequency tabulation. Thus, the inclination of 
empirical nominal data such as mean, median, modus, minimum, and maximum can be obtained. The result of descriptive analysis is important to interpret data by using other techniques.

To obtain representation result, the researcher processes data which have been collected by using suitable analysis tool. Based on theoretical and conceptual frameworks as well as hypotheses, the most suitable analysis model is confirmatory faktor analysis and path analysis, by using software SPSS 18 .

Hypotheses test is performed due to following assumptions: $\mathrm{H}_{\mathrm{a}}$ is accepted if $\mathrm{t}$ hitung $>\mathrm{t}$ tabel, which shows that exogenous variable influences endogenous variable. $\mathrm{H}_{0}$ is accepted if $\mathrm{t}$ hitung $<\mathrm{t}$ tabel, which shows that exogenous variable does not influence endogenous variable. This test is conducted with degree of freedom $95 \% \alpha=0,05$

\section{Result and Discussion}

The result of validity test on 30 items from 9 indicators and 3 variables has the value of $t_{\text {hitung }}>t_{\text {tabel }}$ or Sig $t$ $<0.05$; thus, all question items are valid. The result of reliability test shows that all variables has the value of alpha cronbach $\left(\mathbf{r}_{11}\right)>0.6$; thus, all variables are reliable.

The result of confirmatory factor analysis on Green Marketing construct $\left(\mathrm{X}_{1}\right)$ measured by four indicators: Product $\left(\mathrm{X}_{1.1}\right)$, Price $\left(\mathrm{X}_{1.2}\right)$, Place $\left(\mathrm{X}_{1.3}\right)$, and Promotion $\left(\mathrm{X}_{1.4}\right)$.

From the result of OLS in the first equation, the research can draw on some conclusions:

1. The value of $\mathrm{R}^{2}$ is 0.458 or $45.8 \%$. It means that Interest to Buy $\left(\mathrm{X}_{2}\right)$ is influenced for $45.8 \%$ by Green Marketing $\left(\mathrm{X}_{1}\right)$, and the rest of $54,2 \%$ are influenced by other independent variables which are not discussed in the research.

2. The first equation is: $\mathrm{ZX}_{2}=0.677 \mathrm{ZX}_{1}+\mathrm{e}_{1}$

3. The table shpws that the value of path coefficient (obtained from beta coefficient OLS) is 0.677 , with the value of $t_{\text {hitung }}$ for 9.994 and Sig $t$ for 0.000. Since $t_{\text {hitung }}>t_{\text {tabel }}(9.994>1.981)$ and $\mathrm{Sig} t<0.05(0.000<$ $0.05)$ it can be summed up that Green Marketing $\left(\mathrm{X}_{1}\right)$ has influence on interest to supermarkets in Manado.

Table 1. The Result of OLS

\begin{tabular}{|l|c|c|c|}
\hline \multicolumn{1}{|c|}{ Independent Variable } & Beta & $\mathrm{t}_{\text {hitung }}$ & Sig t \\
\hline Green Marketing $(\mathrm{X} 1)$ & 0.121 & 1.419 & 0.158 \\
\hline Interest to Buy $\left(\mathrm{X}_{2}\right)$ & 0.649 & 7.642 & 0.000 \\
\hline $\mathrm{R}^{2}=0.542$ & & \\
$\mathrm{t}_{\text {tabel }}=1.981$ \\
Dependent Variable $=$ Purchase decision (Y)
\end{tabular}

From the result of OLS in the first equation, the research can draw on some conclusions:

1. The value of $\mathrm{R}^{2}$ is 0.542 or $54.2 \%$. It means that Buying decision (Y) is influenced for $54.2 \%$. by Green Marketing $\left(\mathrm{X}_{1}\right)$ and Buying Interest. and the rest of $45.8 \%$ are influenced by other independent variables which are not discussed in the research.

2. The second equation is: $\mathrm{ZY}=0.121 \mathrm{ZX}_{1}+0.649 \mathrm{ZX}_{2}+\mathrm{e}_{2}$

3. The table shpws that the value of path coefficient (obtained from beta coefficient OLS) between Green Marketing $\left(\mathrm{X}_{1}\right)$ on Purchase decision (Y) is 0.121, with the value of $\mathrm{t}_{\text {hitung }}$ for 1.419 and Sig $\mathrm{t}$ for 0.158 . Since $t_{\text {hitung }}>t_{\text {tabel }}(1.419<1.981)$ and $\operatorname{Sig} t>0.05(0.158>0.05)$ it can be summed up that Green Marketing $\left(\mathrm{X}_{1}\right)$ does not influence on purchase decision $(\mathrm{Y})$ on organic products at supermarkets in Manado

4. The value of path coefficients (obtained from beta coefficient OLS) between buying interest $\left(\mathrm{X}_{2}\right)$ and purchase decision (Y) is 0.649 with the value of $t_{\text {hitung }}$ for 7.642 and Sig $t$ for 0.000 . Since $t_{\text {hitung }}>t_{\text {tabel }}$ $(7.642>1.981)$ and $\mathrm{Sig} t<0.05(0.000<0.05)$ it can be summed up that buying interest $\left(\mathrm{X}_{2}\right)$ has influence on Purchase decision (Y) on organic products at supermarkets in Manado. All path coefficients have positive values (0.649) which indicate a positive correlation. The higher buying interest $\left(\mathrm{X}_{2}\right)$, the higher buying decision $\left(\mathrm{X}_{2}\right)$ for organic products at supermarkets in Manado.

From two equations in path analysis, the researcher is able to describe the result of overall path analysis as follows: 


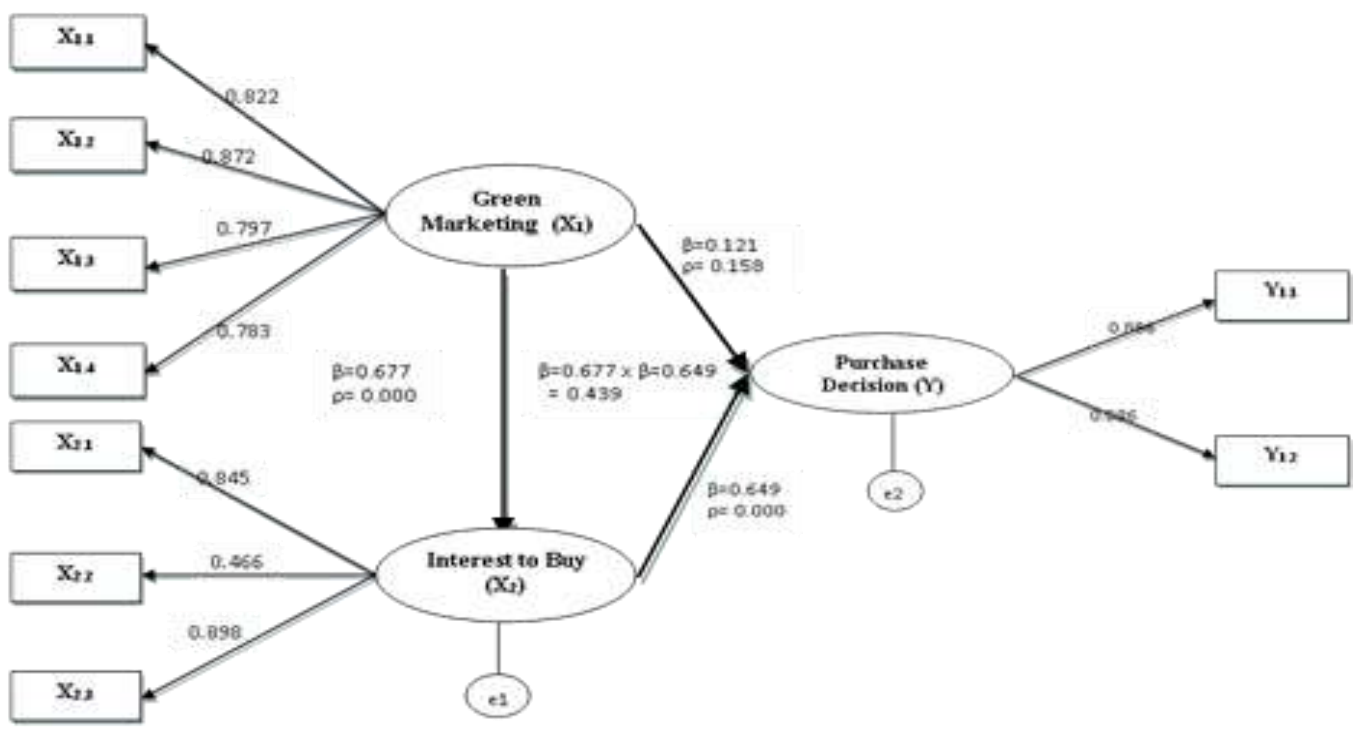

Figure 2. Frame result path analysis

The result of path analysis shows a significant and direct influence $(\beta=0.677 ; \rho=0.000)$ between Green Marketing $\left(\mathrm{X}_{1}\right)$ and Buying Interest $\left(\mathrm{X}_{2}\right)$. It also shows a significant and direct influence $(\beta=0.649 ; \rho=$ 0.000 ) between Buying Interest $\left(\mathrm{X}_{2}\right)$ and Purchase Decision $(\mathrm{Y})$.. However, the result shows no significant and direct influence $(\beta=0.121 ; \rho=0.158)$ between Green Marketing $\left(\mathrm{X}_{1}\right)$ and Purchase Decision (Y). With buying interest as the intervening variable (indirect influence of Green marketing (X1) and Buying Decision $(Y)$, the result shows significant values $(\beta=0.677 \times \beta=0.649)=0.439$.

The result shows that the value of path coefficient (obtained from beta coefficient OLS) is 0.677, with the value of $t_{\text {hitung }}$ for 9.994 and Sig $t$ for 0.000. Since $t_{\text {hitung }}>t_{\text {tabel }}(9.994>1.981)$ and Sig $t<0.05(0.000<$ $0.05)$ it can be summed up that Green Marketing $\left(\mathrm{X}_{1}\right)$ has influence on interest to buy $\left(\mathrm{X}_{2}\right)$. All path coefficients have positive values (0.677) which indicate a positive correlation. The higher Green Marketing $\left(\mathrm{X}_{1}\right)$, the higher customers' interest to buy $\left(\mathrm{X}_{2}\right)$ for organic products at supermarkets in Manado.

The result shpws that direct influence between Green Marketing $\left(\mathrm{X}_{1}\right)$ on Purchase decision (Y) is 0.121 , with the value of $t_{\text {hitung }}$ for 1.419 and Sig $t$ for 0.158 . Since $t_{\text {hitung }}>t_{\text {tabel }}(1.419<1.981)$ and $\operatorname{Sig} t>0.05$ $(0.158>0.05)$ it can be summed up that Green Marketing $\left(\mathrm{X}_{1}\right)$ does not influence on buying decision $(\mathrm{Y})$ on organic products at supermarkets in Manado

The result shows direct influence between buying interest $\left(\mathrm{X}_{2}\right)$ and Purchase decision $(\mathrm{Y})$ is 0.649 with the value of $t_{\text {hitung }}$ for 7.642 and Sig $t$ for 0.000. Since $t_{\text {hitung }}>t_{\text {tabel }}(7.642>1.981)$ and $\operatorname{Sig} t<0.05(0.000<$ $0.05)$ it can be summed up that buying interest $\left(\mathrm{X}_{2}\right)$ has influence on buying decision (Y) on organic products at supermarkets in Manado. All path coefficients have positive values (0.649) which indicate a positive correlation. The higher buying interest $\left(\mathrm{X}_{2}\right)$, the higher buying decision $\left(\mathrm{X}_{2}\right)$ for organic products at supermarkets in Manado.

The result shows direct influence antara Green Marketing $\left(\mathrm{X}_{1}\right)$ on Purchase Decision (Y) thriugh Buying Interest $\left(\mathrm{X}_{2}\right)$. Path coeffcient is obtained from the multiplication of direct influence of Green Marketing $\left(\mathrm{X}_{1}\right)$ on Buying Interest $\left(\mathrm{X}_{2}\right)$ for 0.677. The influence of Buying Interest $\left(\mathrm{X}_{2}\right)$ on Purchase Decision $(\mathrm{Y})$ is 0.649 , so path coefficient has direct influence for $0.677 \times 0.649=0.439$. Since two path coefficients have significant and direct influence, the indirect influence of those path coefficient is also significant. Since path coefficient is positive (0.439), it can be summed up that the higher Green Marketing $\left(\mathrm{X}_{1}\right)$, the higher is Purchase decision (Y), if buying interest $\left(\mathrm{X}_{2}\right)$ also increases.

The last test in path analysis is model validity. In path analysis, the indicator in model validity is total determination coefficients as follows: $R_{\text {total }}^{2}=1-\mathrm{Pe}_{1}{ }^{2} \mathrm{Pe}_{2}{ }^{2} \cdot \mathrm{R}_{\text {total }}^{2}=1-\left(1-\mathrm{R}_{1}{ }^{2}\right)\left(1-\mathrm{R}_{2}{ }^{2}\right) \cdot \mathrm{R}_{\text {total }}^{2}=1-(0.542)$ (0.458). $\mathrm{R}_{\text {total }}^{2}=1-0.248236 . \mathrm{R}_{\text {total }}^{2}=0.7518$ atau $75.18 \%$. where $\mathrm{R}_{1}^{2}=0,458$, and $\mathrm{R}_{2}^{2}=0,542$ respectively is the value of $\mathrm{R}$ square model in the first and second equations. Thus, the value of $\mathrm{R}_{\text {total }}^{2}$ is 0,7518 or $75.18 \%$. From the causal relationship among variables in Path diagram, the total determination coefficient is 0,7518 . It means that $75,18 \%$ information included in data can be explained by using path model. Thus, the path analysis is valid.

\section{The Influence of Green Marketing Toward Interest to Buy}


From the path analysis, it shows that green marketing has direct influence toward buying interest. From positive path coefficient, it shows the higher green marketing, the higher interest of Manado people to buy organic product. It means that the green marketing explains and gives contribution for consumen's interest. The empiric fact supports are stated by Tarkiainen and Sundqvist (2005). They state that price variable and availability or distribution tunnel influence the consumen interest to buy organic product. Fotopoulos dan Krystalis (2002) and Magnusson, et al., (2001) strengthens that consumer desire is influenced by price variables, distribution, and promotion. Tregear, Dent \& McGregor (1994) dan Zanoli \& Naspetti (2002), state that there are several obstacles such as: price and the product availability. Thus, the researcher focuses on two aspects. The strong contribution gives description that Manado is influenced by green marketing that is confirmed by product, price, place, distribution, and promotion.

\section{The Influence of Green Marketing Toward Purchase Decission}

The result shows that direct influence of green marketing does not give significant result in Manado city. Thus the hypothesis and previous research that are done by Tarkiainen and Sundqvist (2005) for costumer in Manado City have not been explained and it is based on analysis result. The green product is different from the convenient and conventional product. In convenient and conventional product, price, place, and promotion give direct influence for buyer to purchase. Organic product is an unique product thus it requires special knowledge and requirements for buyer to decide in buying an organic product. Green marketing is not the only aspect that should be considered. There are still other factors that are capable in forming the understanding the organic product such as interest factor.

\section{The Influence of Interest to Buy Toward Purchase Decission}

The result shows that purchase interest gives direct influence toward purchase decission. The positive path coefficient shows the higher purchase decission will cause the higher interest of people to buy organic product. The purchase decission is confirmed by attitude, subjective norm, and behavior control that are capable in explaining and contributing toward the consumer behavior in buying organic product in Manado. This result is supported by Tarkiainen and Sundqvist (2005) by modificating the theory of plan behavior that shows the significant result in behavior and behavior control. Though, the subjective norm is not strong enough in forming the purchase decission. The same support is from Magistris and Gracia (2008) and Kalafatis, et al., (1999) where the interest variable gives direct impact toward the buying decission. From the previous result, it is confirmed that the organic product is different from the conventional product even from the market segment. From theoritical and empiric data it can be concluded that interest is indicated by behavior, subjective norm, and behavior control are the factors that shape decission of purchasing or organic product in Manado.

\section{The Influence of Green Marketing Toward The Purchase Decisson Through Interest To Buy}

The discussion result shows that green marketing does not give direct influence toward the buying decission. However green marketing influences toward the decission of buying interest. With positive path coefficient shows the higher green marketing aspects such as: product, price, place, promotion and buying interest aspect such as: behavior, subjective norms, and behavior control toward the buying decision.

This means that buying interest is intervening between green marketing and decision to buy organic product in Manado. This result research is supported by Tarkiainen and Sundqvist (2005) who prove that green marketing that is indicated by price and place or availability does not give direct influence toward the customers' decision to buy the products as the intervening variable. Fotopoulos and Krystalis (2002) and Marija Radman (2005), Tsakiridou et al.,(2006), Tregear, Dent and McGregor (1994), Zanoli and Naspetti (2002) conclude that variables in this buying decission influence the green marketing and buying decission. This research also recommends other supportive variables such as: environment and health are the main factors that make costumer buy the green product. Magnusson, et al., (2001), Junaedi (2005) also adds other variables such as: demography, media access, and green marketing as the main variable. The reason why the green marketing becomes the main variable because the characteristic of green product is different from the convenient and conventional product (Lanasier, 2002).

The result of the research and empiric proof can be concluded that buyer interest that is formed by behavior, subjective norm, and behavior control are the variables that are capable in mediating green marketing that is 
shaped from product, price, place and promotion with the decission to buy the organic product. It means that the higher value that is given by the product, the higher decission to buy the organic product that is explained by green marketing toward the costumer in Manado.

\section{Conclussion}

From the analysis and discussion, the research that is entitled Green Marketing's Influence on the Purchase decision to Buy Organic Product with the Interest to Buy as Intervening Variable in Manado Indonesia, can be concluded as followed: Green Marketing has a significant influence toward the interest buyer or costumer to consume organic product. It means that the higher green marketing value, the higher interest of people to buy organic product in Manado. Green Marketing does not give significant value toward the decission to buy organic product for costumer or buyer. This means that the green marketing value is not a measurement for costumer or buyer to decide the organic product in Manado. The buying interest has a significant influence toward the organic product purchase for consumer to buy the organic product in Manado. The higher interest of buying the product, the higher decission to buy the product. The buying interest that is placed as an interviening gives significant influence between Green Marketing with the decission to buy organic product in Manado. It means that the higher value and interest of the green product in Manado, the higher decission to buy the organic product in Manado city, Indonesia.

\section{References}

[1] Ajzen, I. 1988. Attitude, Personality, and Behavior. Dorsey, Chicago, I.L.

[2] Anonim. Makan sehat sambil berevolusi. Kompas, 5 Mei 2007.

[3] Ardianti, N.T, 2008, Analisis perilaku konsumen kota bogor terhadap produk kosmetik hijau MBIPB- Bogor

[4] Charter, M. 1992. Greener Marketing: A Responsible Approach to Business, Greenleaf, Sheffield.

[5] Chen, M.F. 2009. Attitude toward organic foods among Taiwanese as related to health consciousness, environmental attitudes and the mediating effects of a healthy lifestyle, British Food Journal, Vol.111 No. 2, pp.165-78.

[6] Engel, J.F., Blackwell, R.D, and Miniard, P.W., 1994. Perilaku Konsumen. Terjemahan F.X. Budiyanto, Penerbit Binarupa Aksara, Jakarta.

[7] Ferdinand, A. 2006. Metode Penelitian Manajemen: Penelitian Untuk Penulisan Skripsi, Tesis dan Disertasi Ilmu Manajemen. Badan Penerbit Universitas Diponegoro, Semarang.

[8] Fotopoulos, C. and Krystallis, A. 2002b. Purchasing motives and profile of the Greek organic consumer: a countrywide survey, British Food Journal, Vol. 104 No. 3/5, pp. 232-60.

[9] Haryadi, R., 2009. Pengaruh Strategi Green Marketing Terhadap Pilihan Konsumen Melalui Pendekatan Marketing Mix Studi Kasus pada The Body Shop Jakarta, Tesis S2, Universitas Diponegoro, SEMARANG.

[10] Junaedi, S.M.F. 2005. Pengaruh Kesadaran Lingkungan pada Niat Beli Produk Hijau: Studi Perilaku Konsumen Berwawasan Lingkungan, Benefit Jurnal Manajemen dan Bisnis, Vol. 9, No. 2, hal. 189201.

[11] Kalafatis, S., Pollard, M., East, R. and Tsogas, M.H. 1999. Green marketing and Ajzen's theory of planned behaviour: a cross-market examination, Journal of Consumer Marketing, Vol. 16 No. 5, pp. 441-60.

[12] Kasali, Rhenald. 2005. Sembilan Fenomena Bisnis, Manajemen Student Society MSS, FEUI official Site

[13] Kotler, P. dan Keller, K.L.,2007, Manajemen Pemasaran, Cet 2, Edisi 12, Jilid 1, Alih bahasa: Benyamin Molan. Penerbit PT INDEKS

[14] Kotler, P. 2000. Manejemen Pemasaran. Jilid 1,Edisi Millenium, Alih Bahasa: Hendra Teguh, Rony A. Rusly \& Drs.Benyamin Molan, Penerbit, Prentice Hall \& Pearson Education Asia, Jakarta.

[15] Lanasier, E.V. 2002, Perilaku Konsumen Hijau Indonesia: Tinjauan Sudut Demografi dan Psikografi, Media Riset Bisnis dan Manajemen, Volume 2, Nomor 2, PP.89-11, Jakarta

[16] Laroche, M., J. Bergeron, G. Barbaro-Forleo, 2001, Targeting consumers who are willing to pay more for environmentally friendly products, Journal of Consumer Marketing, 18, 6, 503-520.

[17] Lozada, H.R. 2000. Ecological Sustainability and Marketing Strategy : Review and Implication. Seton Hall University 
[18] Ma'ruf, H. 2005. Pemasaran Ritel. Penerbit PT. Gramedia Pustaka Utama. Jakarta.

[19] Magistris, T., and Gracia, A. 2008. The Decision to Buy Organic Food Products in Southern Italy. British Food Journal,Vol.110,No.9,pp929-947.

[20] Magnusson, et al., 2001, Attitudes towards organic foods among Swedish consumers, British Food Journal, Vol. 103 No. 3, pp. 209-26.

[21] Nanere, M. 2010, What Green Marketing Has to Offer, International Conference Indonesian Management Scientist Ass (AIMI). La Trobe University, Bendigo, Australia.

[22] Nugrahadi, E.W. 2002. Pertanian Organik Sebagai Alternatif teknologi Dalam Upaya Menghasilkan Produk Hijau, www.google.com

[23] Ottman, J.A., et al., 2006. Green Marketing Myopia : Ways to Improve Consumer Appeal for Environmentally Preferable Products. Environment Volume 48, Number 5 pp 22-36 Heldref Publications, 2006.

[24] Payne, A. 2000. The Essence of Services Marketing. Terj. Fandy Tjiptono, Penerbit Andi, Yogyakarta.

[25] Polonsky, M.J, Rosenberger, P.J and Ottman, J, 1998, Developing Green Products: Learning From Stakeholder, Asia Pacific Journal or Marketing and Logistics, 10 (1), 22-43.

[26] Pujari, D. and Wright, G. 1995, ' 'Strategic product planning and ecological imperatives towards a taxonomy of strategic, structure and process: a multi-case study of companies in the UK and Germany", MEG Conference, June, University of Bradford, pp. 675-84.

[27] Radman, M. 2005. Consumer Consumption and Perception of organic food Product in Croatia, British Food Journal. Vol.107 No.4

[28] Riduwan, dan Kuncoro. 2007. Analisis Jalur Path Analysis: Cara Menggunakan dan Memakai. Cetakan Kedua, Penerbit, Alfabeta.

[29] Sari, H., 2008., Pemasaran Produk Hijau: Profil Pelanggan Berdasarkan Usia, Gender, Pendidikan dan Pengalaman Membeli, MBA-ITB Volume. 3 No. 4

[30] Sarwono, J. 2007. Analisis Jalur Untuk Riset Bisnis Dengan SPSS. Penerbit Andi, Yogyakarta.

[31] Schiffman, L.G and Kanuk, L.L.,2007. Perilaku Konsumen, Edisi 7, Alih bahasa, Zoelkifli Kasip, Penyunting Bahasa, Rita Maharani, Penerbit PT Indeks, Jakarta.

[32] Sekaran, U., 2006, Research Methods for Business, Buku 1, Edisi 4, Penerjemah Kwan Men Yon, Penerbit Salemba Empat.

[33] Sistya 2002, Profil Konsumen Yang Bersedia Membayar Lebih Banyak Untuk Produk Ramah Lingkungan, Tesis, Program Studi Magister Manajemen Fakultas Ekonomi Universitas Indonesia.

[34] Solomon 2007, Consumer behavior, 7th ed., Pearson Education.

[35] Solomon, M.R., 2002. Consumer Behavior: Buying, Having, and Being. New Jersey, Prestice Hall.

[36] Stanton, W.J. 1991. Fundamental of Marketing. McGraw-Hill Book Company, New York.

[37] Tarkiainen, A. and Sundqvist, S. 2005, Subjective Norms, Attitudes And Intentions Of Finnish Consumers In Buying Organic Food, British Food Journal, Vol. 107 Nos 10-11, pp. 808-22.

[38] Tregear, A., Dent, J.B. and McGregor, M.J. 1994, The demand for organically grown produce, British Food Journal, Vol. 96 No. 4, pp. 21-5.

[39] Tsakiridou E., Konstantinos M.,Tzimitrakalogianni I., 2006. The influence of consumer characteristics and attitudes on the demand for organic olive oil. J Int Food Agrib Market 183/4, 2331

[40] Zanoli, R. and Naspetti, S. 2002, Consumer motivations in the purchase of organic food, British Food Journal, Vol. 104 No. 8, pp. 643-53. 